\title{
DETERMINAN KEJADIAN INFERTILITAS PRIA DI KABUPATEN TULANG BAWANG
}

\author{
Yasmin Julianti S.Ningsih ${ }^{1}$, Achmad Farich ${ }^{2}$ \\ ${ }^{1}$ Puskesmas Gedong Meneng, Tulang Bawang \\ ${ }^{2}$ Program Pasca Sarjana Kesehatan Masyarakat, Universitas Malahayati \\ Email: yasmin.julianti@yahoo.co.id
}

\begin{abstract}
Determine Factors of Men Infertility in Tulang Bawang. Based on the report $\mathrm{MCH}$ (2015) in Tulang bawang 2015 there were 186 cases of infertility. This study aims to determine the factors associated with the infertility in Tulang Bawang years 2015. The result of the bivariate analisys showed that there was a significant relationship between occupation ( $\mathrm{p}$-value $=0,006$; $\mathrm{OR}=4,117$ ), genetics ( $\mathrm{p}$-value=0,039; $\mathrm{OR}=2,952$ ), smooking ( $\mathrm{p}$-value=0,004; $\mathrm{OR}=4,154)$, alcohol (p-value $=0,042 \mathrm{OR}=2,864$ ), and sport ( $\mathrm{p}$-value=0,045; $\mathrm{OR}=2,752$ ). Multivariat analisys result can be explained that occupation ( $\mathrm{p}$-value $=0,032 ; \mathrm{OR}=3,661$ ) experiencing infertility incidence 4,664 times. Its important for a scrining and using a self protection.
\end{abstract}

Keyword: Infertility, Men, Incidence

\begin{abstract}
Abstrak: Determinan Kejadian Infertilitas Pria di Kabupaten Tulang Bawang. Berdasarkan laporan seksi kesehatan keluarga Dinas kesehatan Kabupaten Lampung Barat pada tahun 2014 jumlah kasus kejadian infertilitas pria sebanyak 186 kasus. Metode penelitian case control. Tujuan penelitian adalah untuk mengetahui determinan kejadian infertilitas pria di Kabupaten Tulang bawang tahun 2015. Hasil analisis bivariat menunjukkan bahwa terdapat hubungan yang bermakna antara pekerjaan ( $p$-value $=0,006 ; \mathrm{OR}=4,117)$, riwayat infertilitas dalam keluarga $(p$-value $=0,039$; $\mathrm{OR}=2,952)$, perilaku merokok ( $p$-value $=0,004$; OR=4,154), kebiasaan mengkonsumsi alkohol $(p$ value $=0,042 ; \mathrm{OR}=2,864)$ dan olahraga $(p$-value $=0,045 ; \mathrm{OR}=2,752)$ dengan kejadian kejadian infertilitas pria. Hasil analisis multivariat menunjukkan bahwa faktor yang paling dominan terhadap kejadian infertilitas pria adalah pekerjaan ( $p$-value $=0,032 ; \mathrm{OR}=3,661)$ dimana responden dengan pekerjaan terpapar berisiko 3,661 kali lebih tinggi untuk mengalami kejadian infertilitas pria dibandingkan dengan responden dengan pekerjaan tidak terpapar. Perlu adanya program skrining pranikah dan penyuluhan pentingnya penggunaan alat pelindung diri.
\end{abstract}

Kata Kunci: Infertilitas, Pria, Kejadian

Infertilitas atau ketidak suburan merupakan ketidakmampuan pasangan usia subur (PUS)untuk memperoleh keturunan setelah melakukan hubungan seksual secara teratur dan benar tanpa usaha pencegahan lebih dari satu tahun. Angka satu tahun ditetapkan karena biasanya $85 \%$ pasangan dalam satu tahun sudah memiliki keturunan. Ini berarti, $15 \%$ pasangan usia subur mempunyai masalah infertilitas (Andhyantoro dan Kumalasari, 2012).

Infertilitas atau ketidaksuburan merupakan masalah umum yang mempengaruhi sekitar 10$15 \%$ pasangan. Sepertiga masalah infertilitas pada pasangan terkait dengan organ reproduksi pria. Infertilitas pada pria adalah kondisi kelemahan pria untuk membuat pasangan wanitanya hamil. Selama ini wanita seringkali dianggap sebagai penyebab pasangan suami istri sulit untuk memiliki momongan. Ternyata, berdasarkan penelitian dari organisasi kesehatan dunia (WHO), 11-15\% pasangan sulit memiliki keturunan disebabkan oleh faktor infertilitas dari suami (Triwani, 2013). Infertilitas sekunder adalah ketidakmampuan seseorang memiliki anak atau mempertahankan kehamilannya (HIFERI, 2013). Masalah infertilitas dapat memberikan dampak besar bagi pasangan suami isteri yang mengalaminya, selain menyebabkan masalah medis, infertilitas juga dapat menyebabkan masalah ekonomi maupun psikologis. Secara garis besar, pasangan yang mengalami infertilitas akan menjalani proses panjang dari evaluasi dan pengobatan, dimana proses inidapat menjadi beban fisik dan psikologis bagi pasangan infertilitas (HIFERI, 2013).

Menurut data demografis dunia 12,5 persen pasangan usia subur mengalami kesulitan mendapatkan anak (Triwani, 2013). Indonesia memiliki jumlah penduduk sekitar 238 juta dan diperkirakan prevalensi infertilitas sebanyak 2.647.695. Di Inggris jumlah sperma yang rendah atau kualitas sperma yang jelek merupakan 
penyebab utama infertilitas pada $20 \%$ pasangan. Kualitas semen yang terganggu, azoospermia dan cara senggama yang salah merupakan faktor yang berkontribusi pada $50 \%$ pasangan infertilitas (HIFERI, 2013).

Pemeriksaan analisis sperma sangat penting dilakukan pada awal kunjungan pasutri dengan masalah infertilitas, karena dari berbagai penelitian menunjukkan bahwa faktor lelaki turut memberikan kontribusi sebesar $40 \%$ terhadap kejadian infertilitas (Winkjosastro, 2011). Sekitar $20 \%$ pasangan mengalami kesulitan dalam memperoleh kehamilan. Bila dalam satu tahun pasangan usia subur tidak dapat memperoleh kehamilan setelah melakukan sanggama secara teratur dan tanpa perlindungan maka mereka digolongkan ke dalam pasangan subfertile. $40 \%$ masalah gangguan kesuburan berada pada tubuh pria antara lain kelainan sperma atau hambatan dalam saluran reproduksi pria (vas deferen). Beberapa pria memiliki jumlah sperma yang cukup untuk dapat membuahi sel telur pasangannya dalam test tube sekalipun kadangkadang pria ini sendiri tak sanggup melakukan sanggama. Pada sebagian besar kasus, pasangan semacam ini dapat ditolong dengan menggunakan tehnologi reproduksi terbantu atau asisted reproductive technologies. (Wiknjosastro, 2014).

Sejumlah penelitian menunjukkan bahwa kebiasaan merokok atau obat-obatan dan penggunaan tembakau memberikan pengaruh negatif terkait kesuburan pria. Penggunaan ganja, tembakau dan heroin menyebabkan jumlah sperma berkurang dan meningkatkan risiko memiliki sperma yang abnormal. Hasil penelitian Amarudin (2012) menunjukkan bahwa pria perokok 10-20 batang perhari terbukti menderita kualitas sperma abnormal 8,6 kali lebih besar dibandingkan pria yang tidak merokok.

Mengkonsumsi Alkohol juga dapat mempengaruhi fungsi liver, yang pada gilirannya dapat menyebabkan peningkatan estrogen dan jumlah estrogen yang tinggi dalam tubuh akan memepengaruhi produksi sperma (Triwani, 2013). Konsumsi alkohol yang berlebihan pada laki-laki dapat menyebabkan penurunan kualitas semen (HIFERI, 2013).

Faktor usia juga turut memberi pengaruh terhadap proses spermatogenesis yang berperan dalam proses reproduksi, dimana kualitas dan kuantitasnya makin menurun dengan bertambahnya usia (Kuswanti, 2014).

Angka infertilitas di Indonesia berkisar antara $12-15 \%$, banyaknya pasangan infertilitas di Indonesia dapat diperhitungkan dari banyaknya wanita yang pernah kawin dan tidak mempunyai anak yang masih hidup. Menurut sensus penduduk terdapat $12 \%$ baik di desa maupun di kota atau sekitar 3 juta pasangan infertil tersebar di seluruh Indonesia. Di Provinsi lampung sendiri berdasarkan laporan yang diperoleh dari Dinas kesehatan Provinsi lampung terdapat 1.987 kasus infertilitas dari 1.331.087 pasangan usia subur.

Kabupaten Tulang Bawang merupakan salah satu kabupaten di Provinsi lampung dengan jumlah penduduk usia produktif yang cukup besar. Dari 284.266 penduduk usia produktif, sebanyak 147.661 adalah laki-laki. Sementara jumlah Pasangan Usia Subur (PUS) di Tulang bawang pada tahun 2015 sebanyak 7.4516 ((BPS Tulang Bawang, 2015). Berdasarkan data yang diperoleh dari rekam medik RSUD Menggala, 18 puskesmas serta BPS yang terdapat di wilayah kerja Kabupaten Tulang Bawang pada tahun 2015 terdapat 186 kasus infertilitas pria dari 36.225 pasangan usia subur atau $0,51 \%$. Angka ini mengalami peningkatan bila dibandingkan tahun sebelumnya yang hanya 149 kasus. Angka infertilitas di Kabupaten Tulang Bawang ini lebih tinggi bila dibandingkan dengan Kabupaten lain seperti Kabupaten lampung Utara 112 kasus dari 45.324 PUS, serta Kabupaten Tulang Bawang Barat 56 kasus dari 31. 132 PUS. Dengan angka infertilitas yang tinggi ini dan dampak yang diakibatkan bagi pasangan yang menginginkan kehamilan, maka harus diketahui apa saja yang dapat mempengaruhi keadaan infertilitas tersebut. Peneliti tertarik untuk meneliti determinan kejadian infertilitas pada pria di Kabupaten Tulang Bawang tahun 2015. Tujuan penelitian untuk mengetahui determinan kejadian infertilitas pria di Kabupaten Tulang Bawang tahun 2015.

\section{METODE PENELITIAN}

Jenis penelitian ini merupakan penelitian kuantitatif dengan rancangan observasional analitik dengan pendekatan case control. Penelitian ini akan menilai hubungan kejadian infertilitas pria dengan cara menentukan kelompok kasus dan kelompok kontrol, kemudian mengukur besarnya frekuensi kejadian infertilitas pria pada kedua. Penelitian ini dilakukan dilakukan di Kabupaten Tulang Bawang. Penelitian dilakukan pada bulan AprilMei 2016. Rancangan penelitian ini adalah analitik case control. Rancangan ini dipilih dengan pertimbangan dapat digunakan untuk mencari hubungan seberapa jauh faktor risiko mempengaruhi terjadinya penyakit atau kelainan 
tertentu. Kekuatan hubungan sebab akibat desain kasus kontrol lebih kuat dibandingkan dengan cross sectional study, biasanya murah, cepat memberikan hasil dan tidak memerlukan sampel yang besar.

Populasi kasus dalam penelitian ini seluruh pria dengan infertilitas di kabupaten Tulang bawang yang terdata tahun 2015. Jumlah kasus infertilitas pria di Kabupaten Tulang Bawang tahun 2015 yaitu sebanyak 186 kasus. Sedangkan populasi kontrol dalam penelitian ini pria fertilitas di kabupaten Tulang bawang tahun 2015. Sampel pada kelompok kasus dalam penelitian ini adalah sebagian pria dengan infertilitas di kabupaten Tulang bawang yang terdata tahun 2015. Sampel pada kelompok kontrol adalah sebagian pria fertilitas di Kabupaten Tulang Bawang tahun 2015. Adapun perhitungan besar sampel dihitung dengan menggunakan rumus sampel uji hipotesis beda dua proporsi. Berdasarkan perhitungan sampel di atas maka diperoleh jumlah sampel minimal dalam satu kelompok sebanyak 41 kasus. Peneliti kemudian membuat perbandingan 1:1 sehingga jumlah sampel dalam penelitian ini yaitu sebanyak 41 pada kelompok kasus, dan 41 pada kelompok kontrol, sehingga jumlah total responden sebanyak 82 responden.

Analisis data yang digunakan pada penelitian ini yaitu univariat dan bivariat dengan uji chi suare dan multivariat dengan uji regresi logistik.

\section{HASIL}

\section{a. Hubungan Pekerjaan dengan Infertilitas Pria}

Tabel 1. Hubungan Pekerjaan dengan Infertilitas Pria

\begin{tabular}{|c|c|c|c|c|c|c|}
\hline \multirow{2}{*}{ Pekerjaan } & \multicolumn{2}{|c|}{ Kasus } & \multicolumn{2}{|c|}{ Kontrol } & \multirow{2}{*}{$\begin{array}{c}p \text { - } \\
\text { value }\end{array}$} & \multirow{2}{*}{ OR } \\
\hline & $\mathrm{n}$ & $\%$ & $\mathrm{n}$ & $95 \% \mathrm{CI}$ & & \\
\hline Terpapar & 32 & 78,0 & 9 & 22,0 & \multirow{3}{*}{0,006} & \multirow{3}{*}{$\begin{array}{c}4,117 \\
(1,575- \\
10,764)\end{array}$} \\
\hline $\begin{array}{l}\text { Tidak } \\
\text { terpapar }\end{array}$ & 19 & 46,3 & 22 & 53,7 & & \\
\hline Total & 41 & 100 & 41 & 100 & & \\
\hline
\end{tabular}

Berdasarkan tabel di atas dapat diketahui bahwa sebanyak $32(78,0 \%)$ responden yang bekerja terpapar dengan bahan/zat kimia berbahaya mengalami infertilitas pria dan sebanyak $19(46,3 \%)$ responden yang bekerja tidak terpapar dengan bahan/zat kimia berbahaya mengalami infertilitas pria. Hasil uji statistik didapatkan nilai $\mathrm{p}=0,006(\mathrm{p}<\alpha)$ yang artinya secara statistik terdapat hubungan yang bermakna pekerjaan dengan infertilitas pria. Hasil analisis diperoleh nilai OR sebesar 4,117 (95\% CI: 1,575 - 10,764) yang artinya responden dengan pekerjaan terpapar bahan kimia berbahaya berisiko 4,117 kali lebih tinggi untuk mengalami infertilitas pria dibandingkan dengan responden dengan pekerjaan yang tidak terpapar bahanbahan kimia.

\section{b. Hubungan Riwayat Infertilitas dalam Keluarga dengan Infertilitas Pria}

\begin{tabular}{|c|c|c|c|c|c|c|}
\hline Tabel 2 & Hub & ngan & & $\begin{array}{l}\text { iwayat } \\
\text { as Pria }\end{array}$ & & llitas \\
\hline $\begin{array}{l}\text { Riwayat } \\
\text { Infertilitas }\end{array}$ & $\mathrm{Ka}$ & & & ontrol & $\begin{array}{c}p- \\
\text { - }\end{array}$ & OR \\
\hline Keluarga & $\mathrm{n}$ & $\%$ & $\mathrm{n}$ & $95 \%$ CI & & \\
\hline Ada & 20 & 48,8 & 10 & 24,4 & & 2,952 \\
\hline Tidak & 21 & 51,2 & 31 & 75,6 & 0039 & $(1,154$ \\
\hline Total & 41 & 100 & 41 & 100 & רנס, & $\begin{array}{c}- \\
7,556)\end{array}$ \\
\hline
\end{tabular}

Berdasarkan tabel di atas dapat diketahui bahwa sebanyak $20(48,8 \%)$ responden dengan riwayat infertilitas dalam keluarga mengalami infertilitas pria, dan sebanyak $21 \quad(51,2 \%)$ responden tanpa riwayat infertilitas dalam keluarga mengalami mengalami infertilitas pria. Hasil uji statistik didapatkan nilai $p=0,039$ $(p<\alpha)$ yang artinya secara statistik terdapat hubungan yang bermakna antara riwayat infertilitas dalam keluarga dengan mengalami infertilitas pria. Hasil analisis diperoleh nilai OR sebesar 2,952 (95\% CI: 1,154-7,556) yang artinya responden dengan riwayat infertilitas dalam keluarga berisiko 2,952 kali lebih tinggi untuk mengalami infertilitas pria dibandingkan dengan responden tanpa riwayat infertilitas dalam keluarga.

\section{c. Hubungan Perilaku Merokok Dengan Infertilitas Pria}

\begin{tabular}{|c|c|c|c|c|c|c|}
\hline \multirow{2}{*}{$\begin{array}{l}\text { Perilaku } \\
\text { merokok }\end{array}$} & \multicolumn{2}{|c|}{ Kasus } & \multicolumn{2}{|c|}{ Kontrol } & \multirow{2}{*}{$\begin{array}{c}p- \\
\text { value }\end{array}$} & \multirow{2}{*}{$\begin{array}{c}\text { OR } \\
95 \% \mathrm{CI} \\
\end{array}$} \\
\hline & $\mathrm{n}$ & $\%$ & $\mathrm{n}$ & $\%$ & & \\
\hline Berisiko & 28 & 68,3 & 14 & 34,1 & \multirow[b]{2}{*}{0,004} & \multirow{2}{*}{$\begin{array}{c}4,154 \\
(1,653- \\
10,440)\end{array}$} \\
\hline $\begin{array}{l}\text { Tidak } \\
\text { berisiko }\end{array}$ & 13 & 31,7 & 27 & 65,9 & & \\
\hline
\end{tabular}

Berdasarkan tabel di atas dapat diketahui bahwa sebanyak $28(68,3 \%)$ responden dengan perilaku merokok berisiko mengalami infertilitas pria, dan sebanyak 13 (31,7\%) responden dengan perilaku merokok yang tidak berisiko mengalami 
infertilitas pria. Hasil uji statistik didapatkan nilai $\mathrm{p}=0,004 \quad(\mathrm{p}<\alpha)$ yang artinya secara statistik terdapat hubungan yang bermakna antara perilaku merokok dengan infertilitas pria. Hasil analisis diperoleh nilai OR sebesar 4,154 $(95 \%$ CI: 1,653-10,440) yang artinya responden dengan perilaku merokok yang berisiko, berisiko 4,154 kali lebih tinggi untuk mengalami infertilitas pria dibandingkan dengan responden dengan perilaku merokok yang tidak berisiko.

\section{d. Hubungan Riwayat Mengkonsumsi Alkohol dengan Infertilitas Pria}

Tabel 4. Hubungan Riwayat Mengkonsumsi Alkohol dengan Infertilitas Pria

\begin{tabular}{|c|c|c|c|c|c|c|}
\hline \multirow{2}{*}{$\begin{array}{c}\text { Riwayat } \\
\text { Mengkonsumsi } \\
\text { Alkohol }\end{array}$} & \multicolumn{2}{|c|}{ Kasus } & \multicolumn{2}{|c|}{ Kontrol } & \multirow[b]{2}{*}{$\begin{array}{c}\mathrm{p}- \\
\text { value }\end{array}$} & \multirow{2}{*}{$\begin{array}{c}\text { OR } \\
95 \% \\
\text { CI }\end{array}$} \\
\hline & $\mathrm{n}$ & $\%$ & $\mathrm{n}$ & $\%$ & & \\
\hline Berisiko & 21 & 51,2 & 11 & 26 , & & 2,864 \\
\hline Tidak beris & 20 & 48,8 & 30 & 73,2 & & $(1,138$ \\
\hline Tot & 41 & 100 & 41 & 100 & & $7,209)$ \\
\hline
\end{tabular}

Berdasarkan tabel di atas dapat diketahui bahwa sebanyak $21(51,2 \%)$ responden dengan riwayat mengkonsumsi alkohol yang berisiko mengalami infertilitas pria, dan sebanyak 20 $(48,8 \%)$ responden dengan riwayat mengkonsumsi alkohol yang tidak berisiko mengalami infertilitas pria. Hasil uji statistik didapatkan nilai $\mathrm{p}=0,042$ yang artinya secara statistik terdapat hubungan yang bermakna antara riwayat mengkonsumsi alkohol dengan infertilitas pria. Hasil analisis diperoleh nilai OR sebesar 2,864 (95\% CI: 1,138-7,209) yang artinya responden dengan riwayat mengkonsumsi alkohol yang berisiko, berisiko 2,864 kali lebih tinggi untuk mengalami infertilitas pria dibandingkan dengan responden dengan riwayat mengkonsumsi alkohol yang tidak berisiko.

\section{e. Hubungan Olahraga dengan Infertilitas Pria}

\begin{tabular}{lcccccc} 
Tabel 5. Hubungan & \multicolumn{2}{c}{ Olahraga } & dengan \\
Infertilitas & & & \\
\cline { 1 - 5 } Olahraga & \multicolumn{2}{c}{ Kasus } & \multicolumn{2}{c}{ Kontrol } & $p-$ & OR \\
\cline { 2 - 5 } & $\mathrm{n}$ & $\%$ & $\mathrm{n}$ & $\%$ & value & $95 \% \mathrm{CI}$ \\
\hline Berat & 23 & 56,1 & 13 & 31,7 & & 2,752 \\
\hline Ringan & 18 & 43,9 & 28 & 68,3 & 0,045 & $(1,117-$ \\
\hline Total & 41 & 100 & 41 & 100 & & $6,781)$ \\
\hline
\end{tabular}

Berdasarkan tabel di atas dapat diketahui bahwa sebanyak $23(56,1 \%)$ responden dengan perilaku olahraga berat mengalami infertilitas pria, dan sebanyak $18(43,9 \%)$ responden dengan perilaku olahraga ringan mengalami infertilitas pria. Hasil uji statistik didapatkan nilai $\mathrm{p}=0,045$ yang artinya secara statistik terdapat hubungan yang bermakna antara jenis olahraga dengan infertilitas pria. Dari hasil analisis diperoleh nilai OR sebesar 2,752 (95\% CI: 1,117-6,781) yang artinya responden dengan perilaku olahraga berat berisiko 2,752 kali lebih tinggi untuk mengalami infertilitas pria dibandingkan dengan responden dengan perilaku olahraga ringan.

Pada analisis multivariat uji statistik yang digunakan adalah regresi logistik. Adapun langkah analisis multivariat adalah pemilihan variabel kandidat melalui seleksi bivariat, pembuatan model variabel penentu dan analisis interaksi atau uji interaksi.

Tabel 6. Model multivariat regresi logistik

\begin{tabular}{lcccc}
\hline \multirow{2}{*}{ Variabel } & \multirow{2}{*}{ Sig } & \multirow{2}{*}{$\begin{array}{c}\text { Exp } \\
\text { (B) }\end{array}$} & & \multicolumn{2}{c}{$95 \%$ CI } \\
\hline Pekerjaan & 0,032 & 3,661 & 1,117 & 12,001 \\
\hline $\begin{array}{l}\text { Riwayat } \\
\text { infertilitas } \\
\text { dalam keluarga }\end{array}$ & 0,537 & 1,443 & 0,451 & 4,622 \\
\hline $\begin{array}{l}\text { Perilaku } \\
\text { merokok }\end{array}$ & 0,141 & 2,269 & 0,762 & 6,754 \\
\hline $\begin{array}{l}\text { Kebiasaan } \\
\text { mengkonsumsi } \\
\text { alkohol }\end{array}$ & 0,215 & 1,957 & 0,677 & 5,661 \\
\hline Olahraga & 0,160 & 2,131 & 0,741 & 6,126 \\
\hline
\end{tabular}

Berdasarkan tabel di atas dapat di ketahui bahwa faktor yang paling dominan terhadap kejadian infertilitas pria adalah pekerjaan ( $p$ value $=0,032$ )

\section{PEMBAHASAN}

\section{a. Hubungan Pekerjaan dengan Infertilitas Pria}

Berdasarkan hasil penelitian dapat diketahui juga bahwa sebanyak $32 \quad(78,0 \%)$ responden yang bekerja terpapar dengan bahan/zat kimia berbahaya mengalami infertilitas pria dan sebanyak $19(46,3 \%)$ responden yang bekerja tidak terpapar dengan bahan/zat kimia berbahaya mengalami infertilitas pria. Hasil uji statistik didapatkan nilai $\mathrm{p}=0,006(\mathrm{p}<\alpha)$ yang artinya secara statistik terdapat hubungan yang bermakna pekerjaan dengan infertilitas pria. Hasil analisis diperoleh nilai OR sebesar 4,117 (95\% CI: $1,575-10,764)$ yang artinya responden dengan pekerjaan terpapar bahan kimia berbahaya berisiko 4,117 kali lebih tinggi untuk mengalami infertilitas pria dibandingkan dengan 
responden dengan pekerjaan yang tidak terpapar bahan-bahan kimia.

Hasil penelitian ini sesuai dengan teori yang menyebutkan bahwa terdapat beberapa pekerjan yang melibatkan paparan bahan berbahaya bagi kesuburan seseorang perempuan maupun laki-laki. Setidaknya terdapat 104.000 bahan fisik dan kimia yang berhubungan dengan pekerjaan yang telah teridentifikasi, namun efeknya terhadap kesuburan, $95 \%$ belum dapat diidentifikasi. Bahan yang telah teridentifikasi dapat mempengaruhi kesuburan diantaranya panas, radiasi sinar $\mathrm{X}$, logam dan pestisida.

Paparan terhadap racun seperti lem, bahan pelarut organik yang mudah menguap, silikon, pestisida, obat-obatan (misalnya: obat pelangsing), dan obat rekreasional (rokok, kafein dan alkohol) dapat memengaruhi sistem reproduksi. Kafein terkandung dalam kopi dan teh (Purwoastuti dan Walyani, 2015).

Menurut peneliti variabel pekerjaaan merupakan salah satu faktor risiko kejadian infertilitas pria pada penelitian ini kemungkinan dikarenakan besar persentase para pekerja yang terpapar dengan bahan-zat kimia berbahaya ataupun logam berat pada kelompok pria yang mengalami infertilitas. Keterpaparan para pekerja yang sebagian besar adalah buruh pada beberapa perusahaan perkebunan sawit, karet maupun tebu terjadi selama proses bekerja yang tidak menggunakan alat pengaman diri atau pelindung misalnya pada saat penyemprotan insektisida, pemupukan dan proses pengolahan limbah.

\section{b. Hubungan Riwayat Infertilitas dalam Keluarga dengan Infertilitas Pria}

Berdasarkan hasil penelitian ini dapat diketahui juga bahwa sebanyak $20 \quad(48,8 \%)$ responden dengan riwayat infertilitas dalam keluarga mengalami infertilitas pria, dan sebanyak $21(51,2 \%)$ responden tanpa riwayat infertilitas dalam keluarga mengalami mengalami infertilitas pria. Hasil uji statistik didapatkan nilai $\mathrm{p}=0,039(\mathrm{p}<\alpha)$ yang artinya secara statistik terdapat hubungan yang bermakna antara riwayat infertilitas dalam keluarga dengan mengalami infertilitas pria. Dari hasil analisis diperoleh nilai OR sebesar 2,952 (95\% CI: 1,154-7,556) yang artinya responden dengan riwayat infertilitas dalam keluarga berisiko 2,952 kali lebih tinggi untuk mengalami infertilitas pria dibandingkan dengan responden tanpa riwayat infertilitas dalam keluarga.

Beberapa teori dan penjelasan dari hasil penelitian para ahli ternyata faktor genetik berperan dalam infertilitas pria. Saat ini diketahui banyak penyebab genetik yang mempengaruhi abnormalitas spermatogenesis. Gangguan genetik baik pada jumlah kromosomatau struktur kromosom bisa merusak produksi hormonal atau stimulasi dari spermatogenesis (proses pretesticular), atau akan mengganggu kontrol dari proses spermatogenik itu sendiri (proses testicular). Gangguan genetik/kromosomlainnya (seperti cystic fibrosis dan adult polycystic kidney disease) bisa merusak transportasi sperma (proses posttesticular). Mulai dari kelainan gen sampai kelainan kromosom (Triwani, 2013).

Berdasarkan penelitian dari Organisasi Kesehatan Dunia (WHO), 11-15 persen pasangan sulit memiliki keturunan disebabkan oleh faktor infertilitas dari suami. Menurut peneliti faktor genetik turut berperan dalam terjadinya infertilitas pada pria karena sperma membawa setengah campuran DNA ke sel telur pasangannya, sehingga pria dengan riwayat infertilitas dalam keluarga kemungkinan dapat mengalami infertilitas pula.

\section{c. Hubungan Perilaku Merokok dengan Infertilitas Pria}

Rokok mengandung zat berbahaya bagi oosit (menyebabkan kerusakan oksidatif terhadap mitokondria), sperma (menyebabkan tingginya kerusakan morfologi), dan embrio (menyebabkan keguguran). Kebiasaan merokok pada laki-laki dapat mempengaruhi kualitas ssemen, namum nampaknya terhadap fertilitas belum jelas. Berhenti merokok pada laki-laki dapat meningkatkan kesehatan pada umumnya (HIFERI, 2013).

Berdasarkan hasil penelitian ini dapat diketahui juga bahwa sebanyak $28 \quad(68,3 \%)$ responden dengan perilaku merokok berisiko mengalami infertilitas pria, dan sebanyak 13 $(31,7 \%)$ responden dengan perilaku merokok yang tidak berisiko mengalami infertilitas pria. Hasil uji statistik didapatkan nilai $\mathrm{p}=0,004(\mathrm{p}<\alpha)$ yang artinya secara statistik terdapat hubungan yang bermakna antara perilaku merokok dengan infertilitas pria. Dari hasil analisis diperoleh nilai OR sebesar 4,154 (95\% CI: 1,653 - 10,440) yang artinya responden dengan perilaku merokok yang berisiko, berisiko 4,154 kali lebih tinggi untuk mengalami infertilitas pria dibandingkan dengan responden dengan perilaku merokok yang tidak berisiko.

Penurunan fertilitas perempuan juga terjadi pada perempuan perokok pasif. Penurunan fertilitas juga dialami oleh lelaki yang memiliki kebiasaan merokok (Wiknjosastro, 2011). Kebiasaan merokok baik secara aktif maupun 
pasif, telah diketahui dapat menurunkan kemampuan reproduksi pada pria maupun wanita.

Hasil penelitian ini sejalan dengan penelitian Amarudin (2012) yang menunjukkan bahwa pria perokok $10-20$ batang perhari terbukti menderita kualitas sperma abnormal 8,6 kali lebih besar dibandingkan pria yang tidak merokok.

Hasil analisis multivariat juga menunjukkan bahwa faktor yang paling dominan terhadap kejadian infertilitas pria adalah perilaku merokok ( $p$-value $=0,012)$ dan olahraga ( $p$ value $=0,026)$.

\section{d. Hubungan Kebiasaan Mengkonsumsi Alkohol dengan Infertilitas Pria}

Berdasarkan hasil penelitian ini dapat diketahui juga bahwa bahwa sebanyak 21 $(51,2 \%)$ responden dengan riwayat mengkonsumsi alkohol yang berisiko mengalami infertilitas pria, dan sebanyak $20 \quad(48,8 \%)$ responden dengan riwayat mengkonsumsi alkohol yang tidak berisiko mengalami infertilitas pria. Hasil uji statistik didapatkan nilai $\mathrm{p}=0,042$ yang artinya secara statistik terdapat hubungan yang bermakna antara riwayat mengkonsumsi alkohol dengan infertilitas pria. Dari hasil analisis diperoleh nilai OR sebesar $2,864$ (95\% CI: $1,138-7,209)$ yang artinya responden dengan riwayat mengkonsumsi alkohol yang berisiko, berisiko 2,864 kali lebih tinggi untuk mengalami infertilitas pria dibandingkan dengan responden dengan riwayat mengkonsumsi alkohol yang tidak berisiko.

Alkohol dikatakan dapat berdampak pada fungsi sel Leydig dengan mengurangi sintesis testosteron dan menyebabkan kerusakan pada membran basalis. Konsumsi alkohol yang berlebihan dapat menyebabkan gangguan pada fungsi hipotalamus dan hipofisis. Konsumsi satu atau dua gelas alkohol, satu sampai dua kali per minggu tidak meningkatkan risiko pertumbuhan janin. Konsumsi alkohol tiga atau empat gelas sehari pada laki-laki tidak mempunyai efek terhadap fertilitas. Konsumsi alkohol yang berlebihan pada laki-laki dapat menyebabkan penurunan kualitas semen (HIFERI, 2013).

Pada perempuan tidak terdapat cukup bukti ilmiah yang menyatakan adanya hubungan antara minuman mengandung alkohol dengan peningkatan risiko kejadian infertilitas. Namun, pada lelaki terdapat sebuah laporan yang menyatakan adanya hubungan antara minum alkohol dalam jumlah banyak dengan penurunan kualitas sperma (Wiknjosastro, 2014). Hasil penelitian Idris (2006) menunjukkan bahwa faktor yang berisiko terhadap infertilitas pada laki-laki salah satunya yaitu adanya riwayat minum alkohol. Laki-laki dengan riwayat peminum alkohol berisiko 13,4 kali untuk mengalami keterlambatan konsepsi dibandingkan dengan mereka yang tidak memiliki riwayat sebagai peminum alkohol.

\section{e. Hubungan Aktifitas Olahraga dengan Infertilitas Pria}

$\begin{array}{ccc}\begin{array}{c}\text { Olahraga } \\ \text { meningkatkan }\end{array} & \text { ringan-sedang } & \text { dapat } \\ \text { fertilitas karena akan }\end{array}$
meningkatkan aliran darah dan status anti oksidan. Olahraga berat dapat menurunkan fertilitas. Olahraga >5 jam/minggu, contoh: bersepeda untuk laki-laki. Olahraga >3-5 $\mathrm{jam} / \mathrm{minggu}$, contoh: aerobik untuk perempuan.

Berdasarkan hasil penelitian ini dapat diketahui juga bahwa sebanyak $23 \quad(56,1 \%)$ responden dengan perilaku olahraga berat mengalami infertilitas pria, dan sebanyak 18 $(43,9 \%)$ responden dengan perilaku olahraga ringan mengalami infertilitas pria. Hasil uji statistik didapatkan nilai $p=0,045$ yang artinya secara statistik terdapat hubungan yang bermakna antara jenis olahraga dengan infertilitas pria. Dari hasil analisis diperoleh nilai OR sebesar 2,752 (95\% CI: 1,117 - 6,781) yang artinya responden dengan perilaku olahraga berat berisiko 2,752 kali lebih tinggi untuk mengalami infertilitas pria dibandingkan dengan responden dengan perilaku olahraga ringan.

Menurut peneliti, olahraga memang sangat baik untuk kesuburan pria asal olahraga itu dilakukan dengan benar. Tetapi sangat disayngkan olahragawan mengabaikan kesehatan testis dalam berolahraga. Penggunaan celana dalamyang terlalu ketat dan terlalu lama berolahraga menggunakan sepeda. Kedua hal ini akan menyebabkan gangguan sirkulasi panas pada testis sehingga menyebabkan gangguan pada kinerja testis.

\section{f. Faktor Dominan}

Faktor yang paling dominan terhadap kejadian infertilitas pria adalah pekerjaan ( $p$ value $=0,032)$. Hasil penelitian ini sesuai dengan teori yang menyebutkan bahwa terdapat beberapa pekerjan yang melibatkan paparan bahan berbahaya bagi kesuburan seseorang perempuan maupun laki-laki. Setidaknya terdapat 104.000 bahan fisik dan kimia yang berhubungan dengan pekerjaan yang telah teridentifikasi, namun efeknya terhadap kesuburan, $95 \%$ belum dapat 
diidentifikasi. Bahan yang telah teridentifikasi dapat mempengaruhi kesuburan diantaranya panas, radiasi sinar $\mathrm{X}$, logam dan pestisida.

Paparan terhadap racun seperti lem, bahan pelarut organik yang mudah menguap, silikon, pestisida, obat-obatan (misalnya: obat pelangsing), dan obat rekreasional (rokok, kafein dan alkohol) dapat memengaruhi sistem reproduksi. Kafein terkandung dalam kopi dan teh (Purwoastuti dan Walyani, 2015). Menurut peneliti variabel pekerjaaan merupakan salah satu faktor risiko kejadian infertilitas pria pada penelitian ini kemungkinan dikarenakan besar persentase para pekerja yang terpapar dengan bahan-zat kimia berbahaya ataupun logam berat pada kelompok pria yang mengalami infertilitas. Keterpaparan para pekerja yang sebagian besar adalah buruh pada beberapa perusahaan perkebunan sawit, karet maupun tebu terjadi selama proses bekerja yang tidak menggunakan alat pengaman diri atau pelindung misalnya pada saat penyemprotan insektisida, pemupukan dan proses pengolahan limbah.

Untuk itu perlu dilakukan upaya-upaya pencegahan terhadap penyakit akibat kerja yang dapat berdampak pada infertilitas antara lain dengan mengganti bahan-bahan yang berbahaya dengan bahan-bahan yang kurang berbahaya atau tidak berbahaya sama sekali, misalnya karbon tetraklorida diganti dengan triklor-etilen. Kemudian mengalirkan udara sebanyakbanyaknya menurut perbandingan ke dalam ruang kerja agar bahan-bahan yang berbahaya dari tempat tersebut dapat dialirkan keluar serta menggunakan alat pelindung dalam pekerjaan depat berupa kacamat, masker, helm, sarung tangan, sepatu atau pakaiann khusus yang didisain untuk pekerjaan tertentu. Selain upayaupaya tersebut di atas perlu dilakukan pemeriksaan kesehatan para pekerja secara berkala.

\section{SIMPULAN}

1. Ada hubungan antara pekerjaan dengan kejadian infertilitas pria dengan $p$ value $=0,006$ dan $\mathrm{OR}=4,117$

2. Ada hubungan antara riwayat infertilitas dalam keluarga dengan kejadian infertilitas pria dengan $p$-value $=0,039$ dan $\mathrm{OR}=2,952$
3. Ada hubungan antara perilaku merokok dengan kejadian infertilitas pria dengan $p$ value $=0,004$ dan $\mathrm{OR}=4,154$

4. Ada hubungan antara kebiasaan mengkonsumsi alkohol dengan kejadian infertilitas pria dengan $p$-value $=0,042$ dan $\mathrm{OR}=2,864$

5. Ada hubungan antara kebiasaan mengkonsumsi alkohol dengan kejadian infertilitas pria dengan $p$-value $=0,045$ dan $\mathrm{OR}=2,752$

6. Variabel pekerjaan merupakan variabel yang paling berhubungan dengan infertilitas pria dengan $p$-value $=0,032$ dan $\mathrm{OR}=3,661$

\section{SARAN}

\section{Bagi Dinas Kesehatan}

Bekerja sama dengan pihak perusahaan yang membawahi bidang keselamatan dan kesehatan kerja untuk menerapkan penggunaan alat pelindung diri pada saat bekerja terutama bagi mereka yang kontak langsung dengan bahan/zat kimia berbahaya baik pada saat produksi maupun pengelolaan limbah industri. Melakukan pengawasan kesehatan secara berkala dalam memantau kesehatan para buruh pekerja.

\section{Bagi Masyarakat}

Perlu melakukan skrining pra nikah terhadap pasangan calon pengantin agar dapat terdeteksi awal adanya kelainan pada organ reproduksi dan mendapat penanganan dini yang tepat khususnya bagi mereka yang bekerja dan terpapar dengan bahan/zar kimia berbahaya dalam jangka waktu yang lama. Bagi pasangan yang belum memiliki keturunan agar menghindari jenis pekerjaan yang terpapar langsung dengan bahan/zat kimia berbahaya atau mengajukan mutasi/pindah ke jenis pekerjaan yang tidak kontak langsung dengan bahan/zat berbahaya.

\section{Bagi Peneliti Selanjutnya}

Perlu dilakukan penelitian lebih lanjut mengenai determinan infertilitas pria dengan menggunakan desain penelitian yang lebih baik misalnya dengan desain cohort maupun case control dan variabel yang lebih banyak dan komplek 


\section{DAFTAR PUSTAKA}

Amaruddin. 2012. Tesis: Pengaruh merokok terhadap kualitas sperma pada pria dengan masalah infertilitas studi kasus kontrol di Jakarta. Depok: Fakultas Kesehatan Masyarakat Universitas Indonesia.

Andhyantoro \& Kumalasari. 2012. Kesehatan reproduksi. Penerbit Salemba Medika. Jakarta

HIFERI. 2013. Konsensus Penanganan Infertilitas. Himpunan Endokrinologi Reproduksi dan fertilitas Indonesia.

Idris dkk. 2006. Logam berat, radiasi, diet,rokok, alkohol dan obat-obatan sebagai penyebab infertilitas pria. Jurnal keperawatan
Indonesia, volume 10, No.2, September 2006; hal 70-75.

Kuswanti, I. 2014. Asuhan kehamilan. Yogyakarta: Pustaka Pelajar.

Triwani. 2013. Faktor genetik sebagai salah satu penyebab infertilitas pria. Jurnal Biologi Medik, hal 1-2.

Walyani \& Purwoastuti. 2015. Ilmu obstetri dan ginekologi sosial untuk kebidanan. Yogyakarta: penerbit Pustaka Baru Press.

Winkjosastro. 2011. Ilmu kandungan. Jakarta: Yayasan Bina Pustaka Sarwono Prawirohardjo.

Winkjosastro. 2014. Ilmu kebidanan. Jakarta: Yayasan Bina Pustaka Sarwono Prawirohardjo. 